\title{
Gas exchanges, growth and production of okra cultivated with saline water and silicon fertilization
}

\section{Trocas gasosas, crescimento e produção de quiabeiro cultivado com águas salinas e adubação silicatada}

\author{
Geovani Soares de Lima ${ }^{1 *}$; Cristiane Milenne Alves de Souza'2; Reginaldo Gomes \\ Nobre $^{3}$; Lauriane Almeida dos Anjos Soares ${ }^{4}$; Hans Raj Gheyi ${ }^{5}$; Lourival Ferreira \\ Cavalcante $^{6}$; Pedro Dantas Fernandes ${ }^{7}$; Maria Amanda Guedes ${ }^{2}$
}

\section{Highlights:}

Silicon mitigates the effects of salt stress on stomatal conductance and leaf area.

Salinity induces increases in intercellular $\mathrm{CO}_{2}$ concentration in the substomatal chamber. $\mathrm{CO}_{2}$ assimilation rate is limited by factors of non-stomatal origin.

Okra production is drastically affected by water salinity.

\begin{abstract}
Excess salts in water and/or soil are a critical factor that adversely affects the physiology and growth, besides limiting the production of crops in the semiarid region of Northeast Brazil. One way to reduce the effect of salt stress on plants is by using silicon (Si) fertilization. In this context, the objective of this study was to evaluate the gas exchange, growth, and production of okra cv. Valença as a function of irrigation with saline water and Si doses. The experiment was conducted in a greenhouse in the municipality of Pombal - PB, Brazil. The experimental design adopted was randomized blocks in a 5 $\times 2$ factorial scheme corresponding to five levels of electrical conductivity of water $\mathrm{ECw}(0.3,1.0,1.7$, 2.4 , and $3.1 \mathrm{dS} \mathrm{m}^{-1}$ ) and two doses of Si fertilization (100 and $200 \mathrm{~g}$ of Si per plant), with four replicates. Salt stress increased the intercellular concentration of $\mathrm{CO}_{2}$ in the substomatal chamber and reduced the $\mathrm{CO}_{2}$ assimilation rate, instantaneous carboxylation efficiency, growth, and production of okra plants. Intrinsic water use efficiency and average weights of okra fruits were not influenced by irrigation with saline water and Si doses. The supply of $200 \mathrm{~g}$ Si per plant reduced the deleterious effect of salt stress on stomatal conductance and leaf area of okra, at 45 days after sowing but did not increase production.
\end{abstract}

Key words: Abelmoschus esculentus L. Salt stress. Silicon.

\footnotetext{
1 Prof. Visitante, Unidade Acadêmica de Ciências Agrárias, Universidade Federal de Campina Grande, UFCG, Pombal, PB, Brasil. E-mail: geovani.soares@pq.cnpq.br

2 Discentes, Curso de Graduação em Agronomia, UFCG, Centro de Ciências e Tecnologia Agroalimentar, Pombal, PB, Brasil. E-mail: cristiane1@live.com; amandagueedscc@gmail.com

3 Prof., Departamento de Ciências e Tecnologia, Universidade Federal Rural do Semi-Árido, UFERSA, Caraúbas, RN, Brasil. E-mail: rgomesnobre@yahoo.com.br

4 Prof ${ }^{a}$, Unidade Acadêmica de Ciências Agrárias, UFCG, Pombal, PB, Brasil. E-mail: lauriane.soares@pq.cnpq.br

5 Prof. Visitante, Núcleo de Engenharia de Água e Solo, Universidade Federal do Recôncavo da Bahia, UFRB, Cruz das Almas, BA, Brasil. E-mail: hans@pq.cnpq.br

6 Prof., Centro de Ciências Agrárias, Universidade Federal da Paraíba, UFPB, Areia, PB, Brasil. E-mail: lofeca1946@yahoo.com.br

7 Prof. Visitante, Centro de Tecnologia e Recursos Naturais, UFCG, Campina Grande, PB, Brasil. E-mail: pedrodantasfernandes@ gmail.com

* Author for correspondence
} 


\section{Resumo}

O excesso de sais na água e/ou no solo é um fator crítico que afeta adversamente a fisiologia, o crescimento e limita a produção dos cultivos no semiárido do Nordeste brasileiro. Uma forma de reduzir o efeito do estresse salino sobre as plantas é o uso da adubação com silício. Neste contexto, objetivou-se avaliar as trocas gasosas, o crescimento e a produção do quiabeiro cv. Valença em função da irrigação com águas salinas e doses de silício. $\mathrm{O}$ experimento foi conduzido em casa-de-vegetação no município de Pombal-PB. Adotou-se o delineamento experimental de blocos casualizados, em esquema fatorial 5 x 2, sendo cinco níveis de condutividade elétrica da água - CEa $\left(0,3 ; 1,0 ; 1,7 ; 2,4 \mathrm{e} 3,1 \mathrm{dS} \mathrm{m}^{-1}\right) \mathrm{e}$ duas doses de adubação silicatada ( 100 e $200 \mathrm{~g}_{\text {de }} \mathrm{Si}_{\text {planta }}{ }^{-1}$ ) com quatro repetições. O estresse salino aumentou a concentração intercelular de $\mathrm{CO}_{2}$ na câmera subestomática e reduziu a taxa de assimilação de $\mathrm{CO}_{2}$, a eficiência instantânea de carboxilação, o crescimento e a produção das plantas de quiabeiro. A eficiência intrínseca no uso da água e o peso médio de frutos do quiabeiro não foram influenciados pela irrigação com águas salinas e doses de silício. $\mathrm{O}$ fornecimento de $200 \mathrm{~g} \mathrm{planta}^{-1}$ de silício diminuiu o efeito deletério do estresse salino sobre a condutância estomática e a área foliar de quiabeiro, aos 45 dias após a semeadura, no entanto, não aumentou produção da cultura.

Palavras-chave: Abelmoschus esculentus L. Estresse salino. Silício.

\section{Introduction}

Okra (Abelmoschus esculentus L.) is a vegetable of the Malvaceae family that stands out for its diversification of uses and great acceptance in the market, with small producers being the main ones responsible for its production (Paes, Esteves, \& Sousa, 2012). Okra is an important source of carbohydrates, proteins, fats, minerals and vitamins, and it is a source of calcium, iron and niacin (Santos, Pereira, Medeiros, Costa, \& Pereira, 2019).

In the Northeast region, okra finds favorable edaphoclimatic conditions for its development, standing out as a popular crop among small farmers (A. P. de Oliveira et al., 2014). However, in this region, due to the scarcity of rains and high evapotranspiration demand, the contents of salts in the waters usually increase during the dry season (Souto et al., 2015).

The use of high-salinity water promotes changes in various physiological and metabolic processes, depending on the severity and duration of the stress and, ultimately, affects agricultural production. Initially, salt stress inhibits plant growth due to osmotic stress, which is then followed by ionic toxicity (Munns \& Tester, 2008; Gupta \& Huang, 2014). Salt stress has been shown to reduce overall growth and yield of plants by disrupting various physiological and biochemical processes, such as photosynthesis, ion homeostasis, and enzymatic activities (Hasegawa, 2013; Gondim, Miranda, Gomes, \& Prisco, 2013).

Osmotic stress is linked to the accumulation of ions in the soil solution, whereas nutritional imbalance and the effects of specific ions are related to the accumulation of ions, especially sodium and chloride, at toxic levels that interfere with the availability of elements (Farooq, Hussain, Wakeel, $\&$ Siddique, 2015). After these primary effects, there may be secondary stresses such as oxidative damage, due to the accumulation of reactive oxygen species (ROS), which cause lipid and protein oxidation (Pang \& Wang, 2008). The antioxidant defense system in plant cells includes both enzymatic antioxidants and some non-enzymatic antioxidants (Ashraf, 2009).

Thus, the supply of silicon ( $\mathrm{Si}$ ) can be an alternative to reduce salinity-induced changes in plants, altering soil and plant factors. The mechanisms of salt stress mitigation mediated by $\mathrm{Si}$ include the maintenance of water supply, increase in photosynthesis and reduction of transpiration rates, limitation of oxidative stress, and biosynthetic 
regulation of solutes and plant hormones (Zhu \& Gong, 2014). In addition, Si plays an important role in suppressing the decline of the activities of ROS-eliminating enzymes in the chloroplast, such as superoxidase dismutase (SOD) and ascorbateglutathione pathway enzymes (Cao, Qiang, Qiang, Wang, \& Xu, 2015).

In view of the above, the objective of this study was to evaluate the gas exchanges, growth, and production of okra cv. Valença as a function of irrigation with waters of different levels of salinity and doses of Si.

\section{Material and Methods}

The study was conducted under greenhouse conditions at the Center for Science and Agri-Food Technology of the Federal University of Campina Grande (CCTA/UFCG), situated in the municipality of Pombal, PB, Brazil, located by the geographic coordinates $7^{\circ} 15^{\prime} 18^{\prime \prime} \mathrm{S}$ latitude, $35^{\circ} 52^{\prime} 28^{\prime \prime} \mathrm{W}$ longitude and at an average altitude of $144 \mathrm{~m}$.

The treatments consisted of five levels of electrical conductivity of water $\mathrm{ECw}(0.3,1.0,1.7,2.4$, and
$3.1 \mathrm{dS} \mathrm{m}^{-1}$ ) and two doses of Si fertilization (100 and $200 \mathrm{~g}$ of Si per plant), arranged in randomized block design with four replicates, totaling 40 experimental plots. Irrigation waters with the respective levels of electrical conductivity were prepared by dissolving $\mathrm{NaCl}$ in public-supply water $\left(\mathrm{ECW}=0.30 \mathrm{dS} \mathrm{m}^{-1}\right)$, based on the relationship between $\mathrm{ECW}$ and the concentration of salts $\left(\mathrm{mmol}_{\mathrm{c}} \mathrm{L}^{-1}=10^{*} \mathrm{ECw} \mathrm{dS}\right.$ $\mathrm{m}^{-1}$ ), according to Richards (1954).

Seeds of the okra cultivar Valença were used in this study. This cultivar stands out for its early cycle (harvest between 50 and 60 days), fruits with size of $18 \times 2 \mathrm{~cm}$ and smooth texture. Okra plants were grown in 20 -L pots filled with $23.5 \mathrm{~kg}$ of soil. Before filling the pots, a nonwoven geotextile fabric $\left(\right.$ Bidim $\left.^{\circledR}\right)$ and a $0.3-\mathrm{kg}$ layer of crushed stone were placed at the bottom with two drains to avoid clogging. The soil used to fill the pots was classified as Neossolo Regolitico (Entisol) with sandy-loam texture $(0-30 \mathrm{~cm}$ depth), from the municipality of São Domingos PB. After being pounded to break up clods, the soil was characterized for the physico-chemical attributes (Table 1) according to methodologies proposed by Donagema, Campos, Calderano, Teixeira and Viana (2011).

Table 1

Chemical and physical characteristics of the soil used in the experiment

\begin{tabular}{|c|c|c|c|c|c|c|c|c|}
\hline \multicolumn{9}{|c|}{ Chemical characteristics } \\
\hline $\left.\mathrm{pH} \mathrm{H} \mathrm{H}_{2} \mathrm{O}\right)$ & $\mathrm{OM}$ & $\mathrm{P}$ & $\mathrm{K}^{+}$ & $\mathrm{Na}^{+}$ & $\mathrm{Ca}^{2+}$ & $\mathrm{Mg}^{2+}$ & $\mathrm{Al}^{3+}$ & $\mathrm{H}^{+}$ \\
\hline$(1: 2,5)$ & $\mathrm{g} \mathrm{kg}^{-1}$ & $\left(m g \mathrm{~kg}^{-1}\right)$ & \multicolumn{6}{|c|}{ (n) } \\
\hline 5.58 & 2.93 & 39.2 & 0.23 & 1.64 & 9.07 & 2.78 & 0.00 & 8.61 \\
\hline \multicolumn{9}{|c|}{.......... Chemical characteristics............. } \\
\hline ECse & $\mathrm{CEC}$ & SAR & ESP & \multicolumn{3}{|c|}{ Size fraction $\left(\mathrm{g} \mathrm{kg}^{-1}\right)$} & \multicolumn{2}{|c|}{ Water content (dag kg-1) } \\
\hline$\left(\mathrm{dS} \mathrm{m} \mathrm{m}^{-1}\right)$ & $\mathrm{cmol}_{\mathrm{c}} \mathrm{kg}^{-1}$ & $\left.(\mathrm{mmol} \mathrm{L})^{-1}\right)^{0.5}$ & $\%$ & Sand & Silt & Clay & $33.42 \mathrm{kPa}^{1}$ & $1519.5 \mathrm{kPa}^{2}$ \\
\hline 2.15 & 22.33 & 0.67 & 7.34 & 572.7 & 100.7 & 326.6 & 25.91 & 12.96 \\
\hline
\end{tabular}


Prior to sowing, the soil moisture content was raised until it reached field capacity, using the respective water of each treatment. After sowing, the soil was kept at field capacity with daily irrigations, and the volume to be applied was determined according to the water need of the plants, estimated by the water balance: water volume applied minus water volume drained in the previous irrigation, plus a leaching fraction of 0.10 . Sowing was performed by placing three seeds of okra cv. Valença per pot, at a $2 \mathrm{~cm}$ depth and distributed equidistantly. At 10 days after sowing (DAS), thinning was performed in order to leave only one plant per pot.

Silicon doses were supplied weekly by fertigation, applying 25 and $50 \mathrm{~g}$ of potassium silicate $(50 \%$ $\mathrm{SiO}_{2}$ and $4 \% \mathrm{~K}_{2} \mathrm{O}$ ) in the treatments with 100 and $200 \mathrm{~g}$ of $\mathrm{Si}$ per plant, respectively. Potassium silicate was used as a source of silicon, which was supplied in eight applications. Fertilization with nitrogen, phosphorus, and potassium was performed according to the recommendation of Novais, Neves and Barros (1991), by applying the equivalent of 100,300 , and $150 \mathrm{mg} \mathrm{kg}^{-1}$ of soil of $\mathrm{N}, \mathrm{P}_{2} \mathrm{O}_{5}$, and $\mathrm{K}_{2} \mathrm{O}$, respectively. Monoammonium phosphate was used as a source of nitrogen and phosphorus, with the $\mathrm{N}$ requirement complemented with urea and the $\mathrm{K}$ requirement with potassium chloride. Nitrogen, phosphorus, and potassium were applied weekly. The requirement for micronutrients was met through fortnightly applications of a solution containing $1.0 \mathrm{~g} \mathrm{~L}^{-1}$ of Ubyfol $\left(\mathrm{N}-15 \%, \mathrm{P}_{2} \mathrm{O}_{5-} 15 \%\right.$, $\mathrm{K}_{2} \mathrm{O}-15 \%$, Ca- $1 \%$, Mg- $1.4 \%, \mathrm{~S}-2.7 \%$, Zn- $0.5 \%$, $\mathrm{B}-0.05 \%, \mathrm{Fe}-0.5 \%$, Mn- $0.05 \%, \mathrm{Cu}-0.5 \%$, and Mo$0.02 \%$ ). The sprays were performed on the adaxial and abaxial sides of the leaves.

At 45 days after sowing, i.e., during the stage of intense fruiting of okra plants, the following parameters were evaluated: stomatal conductance $g s\left(\mathrm{~mol} \mathrm{H}_{2} \mathrm{O} \mathrm{m}^{-2} \mathrm{~s}^{-1}\right), \mathrm{CO}_{2}$ assimilation rate $A(\mu \mathrm{mol}$ $\left.\mathrm{m}^{-2} \mathrm{~s}^{-1}\right)$, transpiration $E\left(\mathrm{mmol}\right.$ of $\left.\mathrm{H}_{2} \mathrm{O} \mathrm{m}^{-2} \mathrm{~s}^{-1}\right)$ and internal $\mathrm{CO}_{2}$ concentration $\mathrm{Ci}\left(\mu \mathrm{mol} \mathrm{m} \mathrm{m}^{-2} \mathrm{~s}^{-1}\right)$. After data collection, intrinsic water use efficiency WUEi $(A / g s)\left[\left(\mu \mathrm{mol} \mathrm{m} \mathrm{m}^{-2} \mathrm{~s}^{-1}\right)\left(\mathrm{mmol} \mathrm{H}_{2} \mathrm{O} \mathrm{m}^{-2} \mathrm{~s}^{-1}\right)^{-1}\right]$ and instantaneous carboxylation efficiency CEi $(\mathrm{A} / \mathrm{Ci})$ $\left[\left(\mu \mathrm{mol} \mathrm{m}{ }^{-2} \mathrm{~s}^{-1}\right)(\mu \mathrm{mol} \mathrm{mol})^{1}\right]$ were quantified. Gas exchanges were determined from 7:00 to 9:00 a.m., in fully expanded leaves, using a portable infrared carbon dioxide analyzer (IRGA - LCPro+ Portable Photosynthesis System $^{\circledR}$ ) using constant light of 1,200 $\mu \mathrm{mol}$ of photons $\mathrm{m}^{-2} \mathrm{~s}^{-1}$ and maintained under ambient conditions of $\mathrm{CO}_{2}$ and temperature.

In this same period of evaluation, growth was measured based on plant height (PH), stem diameter (SD) and leaf area (LA). The PH was determined as the distance between the collar of the plant and its apical meristem. The SD was measured $5 \mathrm{~cm}$ from the collar of the plant, and LA was measured using the methodology established by Fideles, Beltrão and Pereira (2010), according to Eq. 1:

$$
\mathrm{Y}=\sum 0.7254(\mathrm{X})^{2.08922}
$$

where $\mathrm{Y}=$ leaf area and $\mathrm{X}=$ midrib length.

At 70 DAS, okra production components were determined through the fresh fruit mass (FFM), total number of fruits (TNF) and average fruit weight (AFW). Fresh fruit mass was measured by weighing all fruits harvested in each experimental plot. The total number of fruits was obtained by summing the fruits produced per plant. The average fruit weight was established through the ratio between fresh fruit mass and the total number of fruits per plant.

The data were subjected to analysis of variance by $\mathrm{F}$ test and, when significant, polynomial regression analysis was performed for the salinity levels factor and means comparison test (Tukey at 0.05 probability level) was performed for Si doses. When there was significant interaction between factors, the Si doses factor was further analyzed considering each level of salinity using the statistical software SISVAR-ESAL (Ferreira, 2014). 


\section{Results and Discussion}

There were significant effects of water salinity levels on stomatal conductance, leaf transpiration, intercellular $\mathrm{CO}_{2}$ concentration, $\mathrm{CO}_{2}$ assimilation rate, and instantaneous carboxylation efficiency
(Table 2). Silicon doses did not significantly influence $(\mathrm{p}>0.05)$ any of the variables analyzed. For interaction between factors $(\mathrm{SL} \times \mathrm{SD})$, there was significant effect only on gs.

Table 2

Summary of analysis of variance for stomatal conductance (gs), leaf transpiration $(E)$, intercellular $\mathrm{CO}_{2}$ concentration $(\mathrm{Ci}), \mathrm{CO}_{2}$ assimilation rate $(A)$, instantaneous carboxylation efficiency $(\mathrm{CEi})$ and intrinsic water use efficiency (WUEi) of okra cv. Valença cultivated with saline waters and silicon doses, 45 days after sowing

\begin{tabular}{lcccccc}
\hline \multirow{2}{*}{ Source of variation } & \multicolumn{7}{c}{ Mean squares } \\
\cline { 2 - 7 } & $g S$ & $E$ & $C i$ & $A$ & $C E i$ & WUEi \\
\hline Saline levels (SL) & $0.016^{* *}$ & $3.13^{*}$ & $7493.34^{*}$ & $185.19^{* *}$ & $0.011^{*}$ & $5939.38^{\text {ns }}$ \\
Linear regression & $0.062^{* *}$ & $12.35^{* *}$ & $29735.15^{*}$ & $673.49^{* *}$ & $0.043^{* *}$ & $140.29^{\text {ns }}$ \\
Quadratic regression & $0.003^{\text {ns }}$ & $0.06^{\text {ns }}$ & $16.00^{\text {ns }}$ & $38.68^{*}$ & $0.041^{* *}$ & $1436.58^{\text {ns }}$ \\
Silicon doses (SD) & $0.000^{\text {ns }}$ & $0.44^{\text {ns }}$ & $37.69^{\text {ns }}$ & $0.40^{\text {ns }}$ & $0.000003^{\text {ns }}$ & $10068.88^{\text {ns }}$ \\
Interaction (SL x SD) & $0.007^{*}$ & $1.75^{\text {ns }}$ & $3954.22^{\text {ns }}$ & $25.89^{\text {ns }}$ & $0.001^{\text {ns }}$ & $10574.29^{\text {ns }}$ \\
Blocks & $0.0008^{\text {ns }}$ & $1.17^{\text {ns }}$ & $8151.75^{\text {ns }}$ & $32.32^{\text {ns }}$ & $0.004^{\text {ns }}$ & $8227.61^{\text {ns }}$ \\
\hline CV $(\%)$ & 16.41 & 20.18 & 26.36 & 11.43 & 23.54 & 15.63 \\
\hline
\end{tabular}

ns, **, respectively not significant and significant at $\mathrm{p}<0.01 ; \mathrm{CV}-$ coefficient of variation.

The stomatal conductance of okra cv. Valença was significantly influenced $(\mathrm{p}<0.05)$ by the interaction between factors $(\mathrm{SL} \times \mathrm{SD})$. Additionally, according to the means comparison test (Figure 1A), there was a significant difference in $g s$ between plants grown under $\mathrm{ECW}$ values of 1.0, 1.7, and $2.4 \mathrm{dS} \mathrm{m}^{-1}$, and the highest values $\left(0.15,0.12\right.$, and $0.12 \mathrm{mmol} \mathrm{H}_{2} \mathrm{O}$ $\mathrm{m}^{-2} \mathrm{~s}^{-1}$ ) were obtained with $\mathrm{Si}$ doses of $200 \mathrm{~g}$ per plant. It is also observed (Figure 1A) that, except for okra plants grown under the lowest and highest levels of ECW $\left(0.3\right.$ and $\left.3.1 \mathrm{dS} \mathrm{m}^{-1}\right)$, the values of $g s$ in plants that received the higher Si dose $(200 \mathrm{~g}$ per plant) were $0.05,0.06$, and $0.095 \mathrm{~mol} \mathrm{H}_{2} \mathrm{O} \mathrm{m}^{-2} \mathrm{~s}^{-1}$ greater than those of plants fertilized with $100 \mathrm{~g}$ of Si per plant under ECW values of 1.0, 1.7, and 2.4 $\mathrm{dS} \mathrm{m} \mathrm{m}^{-1}$, respectively. 

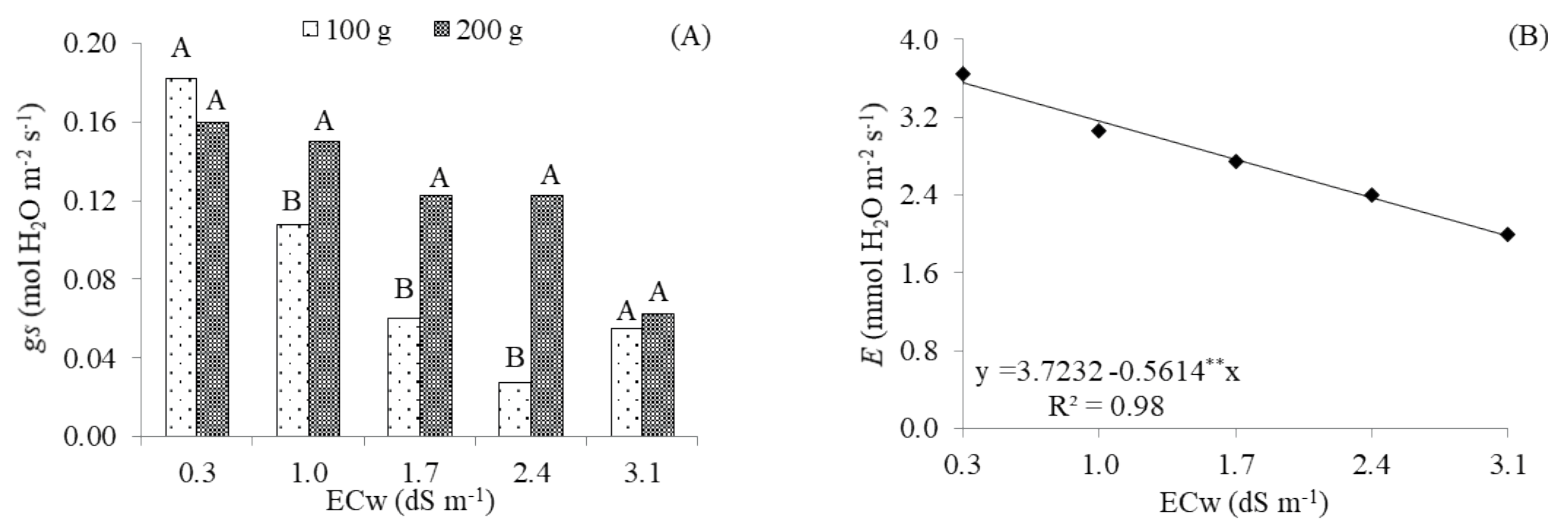

Figure 1. Stomatal conductance - $g s(\mathrm{~A})$ as a function of the interaction between water salinity levels $-\mathrm{ECW}$ and silicon doses, and transpiration - $E$ (B) of okra cv. Valença as a function of ECw levels, at 45 days after sowing.

Means followed by the same letter in the same water salinity level do not differ by Tukey test $(\mathrm{p}<0.05)$.

The greater opening of the stomatal pores for $\mathrm{CO}_{2}$ entry in plants grown under the highest dose of $\mathrm{Si}$ ( $200 \mathrm{~g}$ per plant) is associated with the fundamental role played in the leaves, particularly the control of plant transpiration (Zhu \& Gong, 2014). In addition, $\mathrm{Si}$ acts directly in chlorophyll biosynthesis and improves the structure of chloroplasts in plants grown under salt stress conditions (Haghighi \& Pessarakli, 2013). Unlike the results obtained in this study, Ferraz et al. (2014) evaluated herbaceous cotton genotypes ('BRS Topázio', 'BRS Safira', and 'BRS Rubi') under foliar application of $\mathrm{Si}$ (concentrations ranging from 0 to $200 \mathrm{mg} \mathrm{L}^{-1}$ ) and found that the increase in Si supply through the leaves caused reduction in the stomatal conductance of the 'BRS Topázio' and 'BRS Safira' genotypes.

With the increase in water salinity levels, okra leaf transpiration decreased linearly by $15.07 \%$ per unit increase in $\mathrm{ECw}$ and plants irrigated using water with electrical conductivity of $3.1 \mathrm{dS} \mathrm{m}^{-1}$ reduced their $E$ by $1.57 \mathrm{mmol}_{2} \mathrm{O} \mathrm{m}^{-2} \mathrm{~s}^{-1}$ (Figure 1B) compared to those receiving the lowest level of salinity $\left(0.3 \mathrm{dS} \mathrm{m}^{-1}\right)$. The imposition of salt stress resulted in a marked reduction in the $E$ of okra plants, which is explained by the decrease in the osmotic potential of the soil solution. According to Prazeres et al. (2015), the decrease in transpiration is directly related to the decrease in stomatal conductance, because with smaller stomatal openings there will be a reduction in water loss to the atmosphere, thus maintaining cell turgor. Reductions in plant transpiration in response to salt stress have been observed by several authors (Lúcio et al., 2013; G. S. Lima et al., 2017) and have been attributed to stomatal and non-stomatal causes associated with the osmotic and toxic effects of excess salts (Lúcio et al., 2013).

The intercellular $\mathrm{CO}_{2}$ concentration of okra plants increased linearly as a function of the increase in water salinity levels. The regression equation (Figure 2A) showed a $17.83 \%$ increment per unit increase in ECw. Okra plants subjected to an ECW of $3.1 \mathrm{dS} \mathrm{m}^{-1}$ had an increase in the intercellular $\mathrm{CO}_{2}$ concentration of $47.59 \%\left(77.11 \mathrm{mmol} \mathrm{H}_{2} \mathrm{O}\right.$ $\left.\mathrm{m}^{-2} \mathrm{~s}^{-1}\right)$ compared to those that received the lowest level of water salinity $\left(0.3 \mathrm{dS} \mathrm{m}^{-1}\right)$. Although the partial closure of stomata, observed in this study through the reduction in stomatal conductance (Figure 1A), causes reduction in $\mathrm{Ci}$, there was an increase in the intercellular concentration of $\mathrm{CO}_{2}$ in the substomatal chamber due to the inhibition of electron transport and the photophosphorylation activity, which is explained by the decrease in photosynthetic activity (Suassuna et al., 2014). 
Similar results were obtained by G. S. Lima et al. (2017) in a study evaluating the gas exchange of colored cotton as a function of irrigation with waters of different levels of salinity (ECw from 5.1 to 9.1 $\mathrm{dS} \mathrm{m}{ }^{-1}$ ). These authors observed that the increase in water salinity levels did not limit the entry of $\mathrm{CO}_{2}$ in the substomatal chamber of cotton plants, and the highest $C i$ was observed in plants grown with an ECw of $9.1 \mathrm{dS} \mathrm{m}^{-1}$.
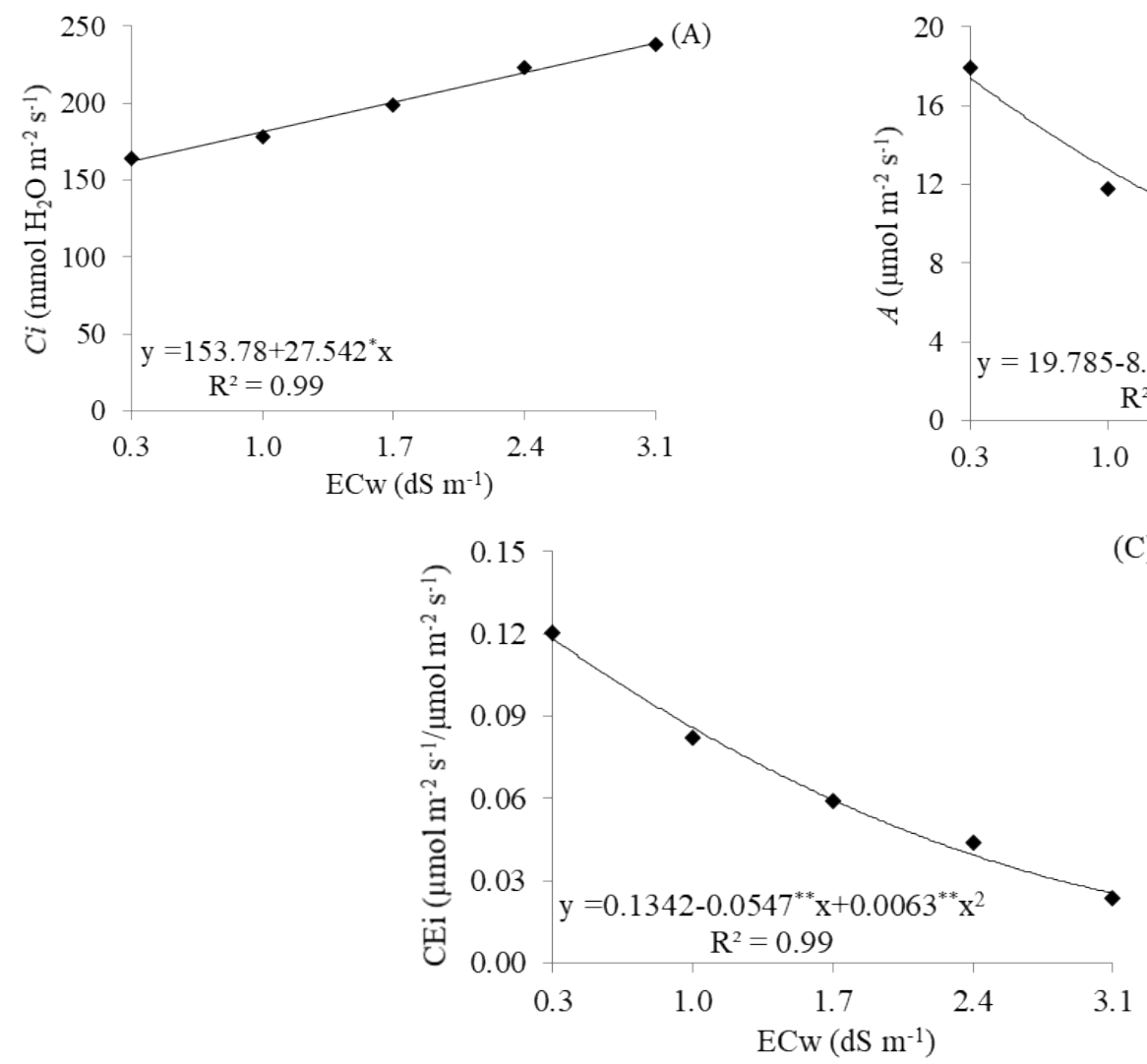

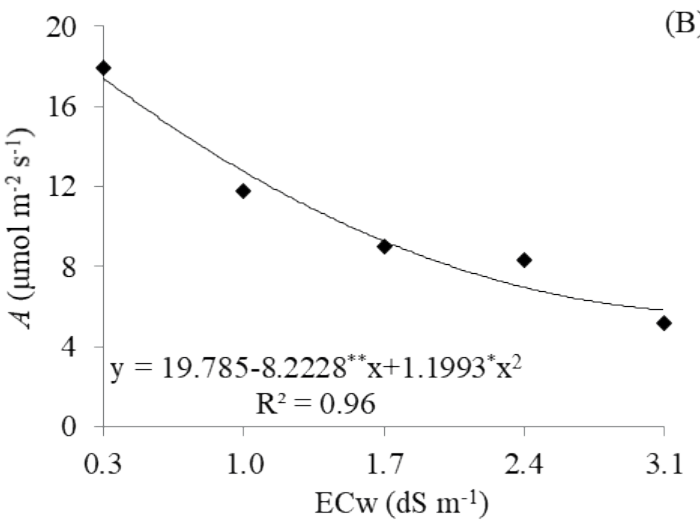

(C)

Figure 2. Intercellular $\mathrm{CO}_{2}$ concentration - $\mathrm{Ci}(\mathrm{A}), \mathrm{CO}_{2}$ assimilation rate - $A(\mathrm{~B})$ and instantaneous carboxylation efficiency - CEi (C) of okra cv. Valença, as a function of the levels of water salinity - ECw, at 45 days after sowing.

The $\mathrm{CO}_{2}$ assimilation rate of okra reduced quadratically with the increase in irrigation water salinity. According to the regression equation (Figure 2B), plants cultivated with $\mathrm{ECw}$ of 0.3 $\mathrm{dS} \mathrm{m}^{-1}$ had the maximum value for $A(17.42 \mu \mathrm{mol}$ $\left.\mathrm{m}^{-2} \mathrm{~s}^{-1}\right)$, which decreased from this level on and reached the lowest value $\left(5.82 \mu \mathrm{mol} \mathrm{m} \mathrm{m}^{-2} \mathrm{~s}^{-1}\right)$ in plants cultivated under ECw of $3.1 \mathrm{dS} \mathrm{m}^{-1}$. In a comparison of the $\mathrm{CO}_{2}$ assimilation rates between plants subjected to ECw of 3.1 and $0.3 \mathrm{dS} \mathrm{m}^{-1}$, there was a decrease of $11.60 \mu \mathrm{mol} \mathrm{m} \mathrm{m}^{-2} \mathrm{~s}^{-1}$. The decrease in $\mathrm{CO}_{2}$ assimilation by okra plants may be related to the action of non-stomatal factors, considering that there was no reduction in $\mathrm{CO}_{2}$ availability in the substomatal chamber. Under conditions of high salinity, there may be inhibition in the activity of the enzyme ribulose-1,5-bisphosphate carboxylase oxygenase ( $\mathrm{RuBisCO}$ ), leading to lower rate in carbon assimilation by plants (Melo et al., 2009). Unlike the results obtained in this study, Souza, Machado, Silveira and Ribeiro (2011) concluded that reductions in the net $\mathrm{CO}_{2}$ assimilation of 
common bean under salt stress are caused by the decrease in stomatal opening, accompanied by the decrease in the apparent efficiency of carboxylation.

The instantaneous carboxylation efficiency of okra plants also decreased quadratically as the levels of irrigation water salinity increased. According to the regression equation (Figure 2C), the maximum value for CEi was $0.118\left[\mu \mathrm{mol} \mathrm{m} \mathrm{m}^{-2}\right.$ $\left.\mathrm{s}^{-1}\left(\mu \mathrm{mol} \mathrm{m} \mathrm{m}^{-2} \mathrm{~s}^{-1}\right)^{-1}\right]$, observed in plants grown under $\mathrm{ECw}$ of $0.3 \mathrm{dS} \mathrm{m}^{-1}$, decreasing from this salinity level and reaching the minimum value of 0.025 $\left[\mu \mathrm{mol} \mathrm{m}^{-2} \mathrm{~s}^{-1}\left(\mu \mathrm{mmol}^{-2} \mathrm{~s}^{-1}\right)^{-1}\right]$. There was a reduction of $0.093\left[\mu \mathrm{mol} \mathrm{m} \mathrm{m}^{-2} \mathrm{~s}^{-1}\left(\mu \mathrm{mol} \mathrm{m} \mathrm{m}^{-2} \mathrm{~s}^{-1}\right)^{-1}\right]$ in the CEi of okra plants subjected to water salinity of $3.1 \mathrm{dS}$ $\mathrm{m}^{-1}$, compared to those irrigated using water with $\mathrm{ECw}$ of $0.3 \mathrm{dS} \mathrm{m} \mathrm{m}^{-1}$. Reduction in instantaneous carboxylation efficiency is an indication that there were limitations of non-stomatal origin, notably the factors that have biochemical origin (Melo et al., 2009). According to Silva, Ribeiro, Ferreira-Silva, Viégas and Silveira (2011a), the reduction in CEi is associated with decreased $\mathrm{RuBisCO}$ activity. Oliveira, Souza, Cunha, Silva and Veloso (2017), in an experiment with cowpea irrigated using water with six levels of electrical conductivity $(0,2.5,5.0$, $7.5,10.0$, and $12.5 \mathrm{dS} \mathrm{m}^{-1}$ ), also reported that there was a linear decrease in CEi as a function of the increase in $\mathrm{ECw}$ levels.

According to the analysis of variance summary (Table 3), there was significant effect of salinity levels on the PH, SD, LA, FFM, and TNF of okra plants. Silicon doses did not significantly influence $(p>0.05)$ any of the variables analyzed. The interaction between the studied factors $(\mathrm{SL} \times \mathrm{SD})$ caused significant difference $(p<0.05)$ only in the leaf area of okra.

\section{Table 3}

Summary of analysis of variance for plant height (PH), stem diameter (SD), leaf area (LA), at 45 days after sowing (DAS) and total number of fruits (TNF), fresh fruit mass (FFM), and average fruit weight (AFW) of okra cv. Valença cultivated with saline water and silicon doses at 70 DAS

\begin{tabular}{lcccccc}
\hline \multicolumn{1}{c}{ Source of variation } & \multicolumn{5}{c}{ Mean squares } \\
\hline \multicolumn{1}{c}{ PH } & & SD & LA & TNF & FFM & AFW \\
\hline Saline levels (SL) & $484.85^{* *}$ & $30.67^{* *}$ & $4947274.60^{* *}$ & $178.65^{* *}$ & $22896.80^{* *}$ & $9.16^{\text {ns }}$ \\
Linear regression & $1806.00^{* *}$ & $107.71^{* *}$ & $18104057.41^{* *}$ & $638.45^{* *}$ & $80311.96^{* *}$ & $1.58^{\text {ns }}$ \\
Quadratic regression & $0.57^{\text {ns }}$ & $12.68^{\text {ns }}$ & $1353163.56^{\text {ns }}$ & $54.32^{*}$ & $2944.51^{\text {ns }}$ & $12.01^{\text {ns }}$ \\
Silicon doses (SD) & $57.60^{\text {ns }}$ & $2.82^{\text {ns }}$ & $222946.70^{\text {ns }}$ & $6.40^{\text {ns }}$ & $1405.05^{\text {ns }}$ & $1.44^{\text {ns }}$ \\
Interaction (SL x SD) & $22.22^{\text {ns }}$ & $4.75^{\text {ns }}$ & $1579207.65^{*}$ & $9.02^{\text {ns }}$ & $957.18^{\text {ns }}$ & $5.32^{\text {ns }}$ \\
Blocks & $38.73^{\text {ns }}$ & $11.89^{\text {ns }}$ & $806620.52^{\text {ns }}$ & $3.90^{\text {ns }}$ & $838.40^{\text {ns }}$ & $6.62^{\text {ns }}$ \\
\hline CV $(\%)$ & 17.71 & 11.06 & 28.30 & 28.62 & 24.26 & 19.75 \\
\hline
\end{tabular}

ns,$* *$, respectively not significant and significant at $\mathrm{p}<0.01 ; \mathrm{CV}-$ coefficient of variation.

The height of okra plants decreased linearly with the increase in the levels of irrigation water salinity and, based on the regression equation (Figure 3A), there were reductions of $12.26 \%$ per unit increase in $\mathrm{ECw}$, i.e., plants grown under water salinity of $3.1 \mathrm{dS} \mathrm{m}^{-1}$ reduced their PH by $18.99 \mathrm{~cm}$ (35.64\%) in comparison to those under irrigation with $\mathrm{ECW}$ of $0.3 \mathrm{dS} \mathrm{m}^{-1}$. Inhibition of plant growth under salt stress is the result of the osmotic effect of the saline solution, as well as imbalance in nutrient absorption and assimilation, and ionic toxicity on the metabolism (Rezende et al., 2018). For Kaushal \& Wani (2016), excess salts in water and/or soil reduces plant growth due to the reduction in the water potential of the soil solution, inhibiting water absorption by roots and causing decrease in cell 
expansion, due to lower cell turgor and consequently lower cell division. In agreement with the present study, Vieira, Nobre, Dias and Pinheiro (2016) also observed reduction in the height of tomato plants, under irrigation with saline water (ECw: 0.3 to 4.5 $\left.\mathrm{dS} \mathrm{m}^{-1}\right)$.

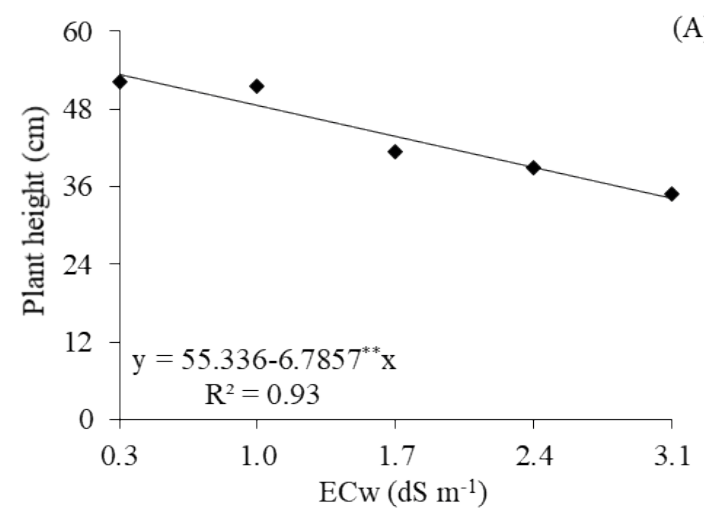

(A)
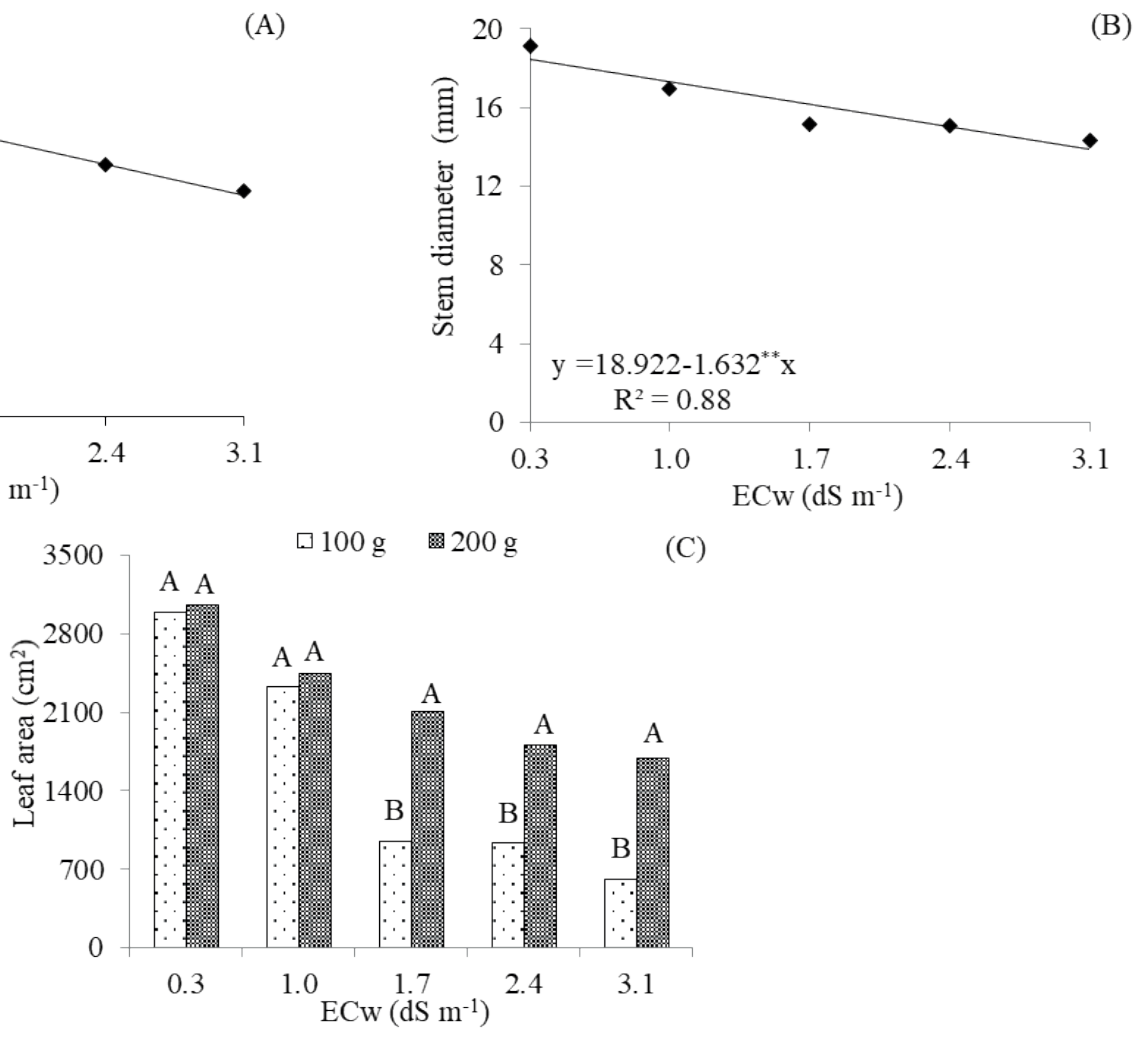

Figure 3. Plant height (A), stem diameter (B), as a function of water salinity levels - ECW and leaf area (C) of okra cv. Valença, as a function of the interaction between ECw levels and silicon doses, at 45 days after sowing. Means followed by the same letter do not differ by Tukey test $(\mathrm{p}<0.05)$.

Okra stem diameter decreased linearly as a function of the increase in water salinity levels, at 45 DAS. According to the regression equation (Figure 3B), there was an $8.63 \%$ decrease per unit increase in ECw. The SD decreased by $4.56 \mathrm{~mm}$ between okra plants cultivated under an ECw of $3.1 \mathrm{dS} \mathrm{m}^{-1}$ and those subjected to the lowest level of water salinity $\left(0.3 \mathrm{dS} \mathrm{m}^{-1}\right)$. Excess salts in water reduce the capacity of plants to absorb water and nutrients, immediately causing reductions in growth and interference in the processes of $\mathrm{CO}_{2}$ assimilation (Figure 2B). These processes include translocation of carbohydrates to sink tissues, and in the diversion of sources of energy to other processes, such as osmotic adjustment, synthesis of compatible solutes, repair of damage caused by salinity, and maintenance of basic metabolic processes (Lucena, Siqueira, Martinez, \& Cecon, 2012). In the bell peppers, G. S. Lima et al. (2016) found that the increase in $\mathrm{ECW}$ from 0.6 to $3.0 \mathrm{dS}$ $\mathrm{m}^{-1}$ resulted in a marked reduction in the growth in stem diameter, at 90 days after transplanting.

As observed for $g s$ (Figure 1A), the leaf area of okra plants was also significantly affected $(\mathrm{p}<$ $0.05)$ by the interaction between factors $(\mathrm{SL} \times \mathrm{SD})$, at 45 DAS. The means comparison test (Figure 3C) shows that, except for plants subjected $\mathrm{ECw}$ of 0.3 and $1.0 \mathrm{dS} \mathrm{m}^{-1}$, the application of Si at dose of 200 g per plant promoted greater growth in leaf areas of 
plants irrigated using water with salinities of 1.7, 2.4, and $3.1 \mathrm{dS} \mathrm{m}^{-1}$. When comparing the leaf area of plants fertilized with $200 \mathrm{~g}$ per plant to the leaf area of plants that received $100 \mathrm{~g}$ per plant, there was superiority of $1149.91,872.54$ and $1080.13 \mathrm{~cm}^{2}$ at $\mathrm{ECw}$ levels of $1.7,2.4$, and $3.1 \mathrm{dS} \mathrm{m}^{-1}$, respectively.

According to Currie \& Perry (2007), the effect of $\mathrm{Si}$ on plants becomes evident in plants grown under stress, whether biotic or abiotic. This statement is confirmed in the present study, since okra plants obtained greater growth in leaf areas when subjected to higher levels of $\mathrm{ECw}\left(1.7,2.4\right.$, and $\left.3.1 \mathrm{dS} \mathrm{m}^{-1}\right)$ and a Si dose of $200 \mathrm{~g}$ per plant. Lima, Castro, Vidal and Enéas (2011) adds that Si has a beneficial effect, as it acts on the optimization of biochemical and physiological processes, ultimately affecting the leaf expansion of crops. For Moussa \& Galad (2015), adequate supply of Si contributed to greater efficiency in the absorption of other ions that are essential to plant metabolism.

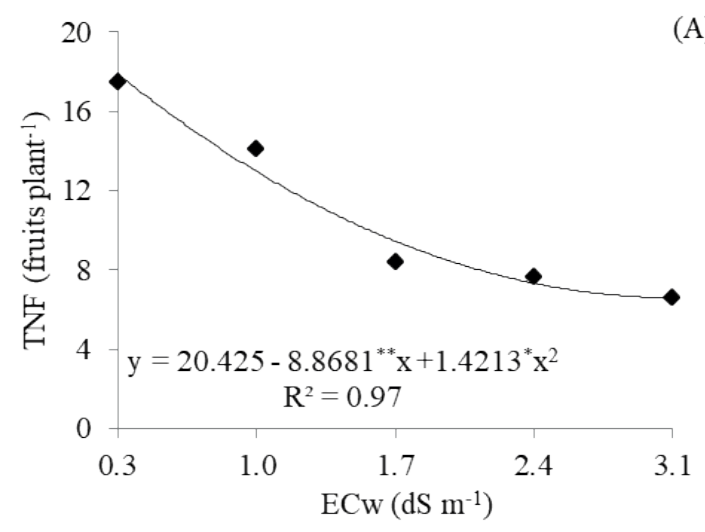

The total number of okra fruits decreased quadratically (Figure 4A) with the increase in the levels of electrical conductivity of water, and the maximum value was obtained when the plants were irrigated using water with ECw of $0.3 \mathrm{dS} \mathrm{m}^{-1}$ (17.89 fruits per plant). However, the minimum value (6.59 fruits per plant) was observed in plants subjected to the highest level of water salinity $\left(3.1 \mathrm{dS} \mathrm{m}^{-1}\right)$. The drastic reduction in the number of fruits is likely the result of osmotic and ionic effects of the soil solution and reduction in the total water potential, which stands out as a progressive factor of physiological disorders in plants, compromising the production of several crops cultivated under salt stress (Silva et al., 2011b). Reductions in the number of fruits as a function of salt stress were also observed by G. S. Lima et al. (2016) in bell pepper and Medeiros, Duarte, Uyeda, Silva and Medeiros (2012) in tomato.

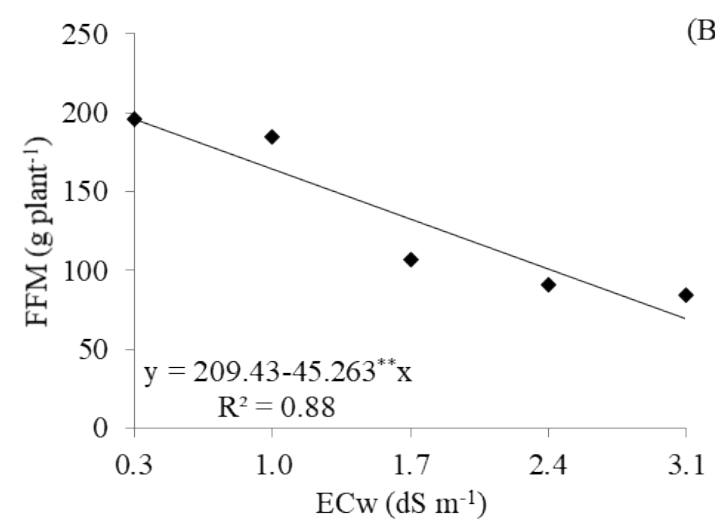

(B)

Figure 4. Total number of fruits - TNF (A) and fresh fruit mass - FFM (B) per plant of okra cv. Valença, as a function of water salinity levels - ECw, 70 days after sowing.

The fresh mass of okra fruits decreased linearly with the increase in the levels of irrigation water salinity. According to the regression equation (Figure 4B), there was a reduction in FFM of $21.61 \%$ per unit increase in ECw. FFM decreased by $126.73 \mathrm{~g}$ per plant $(64.71 \%)$ in plants cultivated with $\mathrm{ECw}$ of $3.1 \mathrm{dS} \mathrm{m} \mathrm{m}^{-1}$ compared to those under irrigation with the lowest ECw level $\left(0.3 \mathrm{dS} \mathrm{m}^{-1}\right)$. The low water potential caused by the reduction of osmotic potential usually inhibits plant production. Such reduction in the FFM of okra plants can be attributed to the decrease in carbon assimilation (Figure 2B), due to non-stomatal limitation and/ or metabolic impairment (Hajiboland, Norouzi, 
\& Poschenrieder, 2014), due to the expenditure of energy to maintain the biosynthesis of osmotic solutes and generate the amount of energy necessary for this biosynthesis. In addition, other important processes for the osmotic adjustment of plants contribute to the change in carbon flux for fruit formation and, consequently, induce the decrease in fresh fruit mass (Larré, Moraes, \& Lopes, 2011). Lima et al. (2016), evaluating the growth and production of 'All Big' bell pepper, as a function of irrigation with saline water ( 0.6 and $\left.3.0 \mathrm{dS} \mathrm{m}^{-1}\right)$, observed a marked reduction in the number of fruits per plant, fresh fruit mass and average fruit weight when using ECw of $3.0 \mathrm{dS} \mathrm{m}^{-1}$.

\section{Conclusions}

Water salinity reduces the $\mathrm{CO}_{2}$ assimilation rate and the instantaneous carboxylation efficiency, growth and production of okra cv. Valença.

The effects of salinity on the photosynthesis rate are associated with stomatal and non-stomatal factors.

The intrinsic water use efficiency and average weight of okra fruits are not influenced by irrigation with saline water and silicon doses.

Silicon application at the $200 \mathrm{~g}$ per plant dose reduces the deleterious effect of water salinity on the stomatal conductance and leaf area of okra plants at 45 days after sowing, but it does not result in an increase of production.

\section{References}

Ashraf, M. (2009). Biotechnological approach of improving plant salt tolerance using antioxidants as markers. Biotechnology Advances, 27(1), 84-93. doi: 10.1016/j.biotechadv.2008.09.003

Cao, B. L., Qiang, M. A., Qiang, Z., Wang, L., \& Xu, K. (2015). Effects of silicon on absorbed light allocation, antioxidant enzymes and ultrastructure of chloroplasts in tomato leaves under simulated drought stress. Scientia Horticulturae, 194(14), 5362. doi: 10.1016/j.scienta.2015.07.037
Currie, H. A., \& Perry, C. C. (2007). Silica in plants: biological, biochemical and chemical studies. Annals of Botany, 100(7), 1383-1389. doi: 10.1093/ aob/mcm247

Donagema, G. K., Campos, D. V. B. de, Calderano, S. B., Teixeira, W. G., \& Viana, J. H. M. (Org.) (2011). Manual de métodos de análise de solos (2a ed., rev.). (EMBRAPA Solos. Documentos, 132). Rio de Janeiro: EMBRAPA Solos.

Farooq, M., Hussain, M., Wakeel, A., \& Siddique, K. H. M. (2015). Salt stress in maize: effects, resistance mechanisms, and management. A review. Agronomy for Sustainable Development, 35(2), 461-481. doi: 10.1007/s13593-015-0287-0

Ferraz, R. L. de S., Beltrão, N. E. de M., Melo, A. S. de, Magalhães, I. D., Fernandes, P. D., \& Rocha, M. do S. (2014). Trocas gasosas e eficiência fotoquímica de cultivares de algodoeiro herbáceo sob aplicação de silício foliar. Semina: Ciências Agrárias, 35(2), 735748. doi: 10.5433/1679-0359.2014v35n2p735

Ferreira, D. F. (2014). Sisvar: a guide for its bootstrap procedures in multiple comparisons. Ciência $e$ Agrotecnologia, 38(2), 109-112. doi: 10.1590/ S1413-70542014000200001

Fideles, J., Fo., Beltrão, N. E. M., \& Pereira, A. S. (2010). Desenvolvimento de uma régua para medidas de área foliar do algodoeiro. Revista Brasileira de Engenharia Agrícola e Ambiental, 14(7), 736-741. doi: $10.1590 / \mathrm{S} 1415-43662010000700008$

Gondim, F. A., Miranda, R. de S., Gomes, E., Fº, \& Prisco, J. T. (2013). Enhanced salt tolerance in maize plants induced by $\mathrm{H}_{2} \mathrm{O}_{2}$ leaf spraying is associated with improved gas exchange rather than with nonenzymatic antioxidant system. Theoretical and Experimental Plant Physiology, 25(4), 251-260. doi: $10.1590 /$ S2197-00252013000400003

Gupta, B., \& Huang, B. (2014). Mechanism of salinity tolerance in plants: physiological, biochemical, and molecular characterization. International Journal of Genomics, 2014(1), 1-18. doi: 10.1155/2014/ 701596

Haghighi, M., \& Pessarakli, M. (2013). Influence of silicon and nano-silicon on salinity tolerance of cherry tomatoes (Solanum lycopersicum L.) at early growth stage. Scientia Horticulturae, 161(24), 111117. doi: 10.1016/j.scienta.2013.06.034

Hajiboland, R., Norouzi. F., \& Poschenrieder, C. (2014). Growth, physiological, biochemical and ionic responses of pistachio seedlings to mild and high salinity. Trees, 28(4), 1065-1078. doi: 10.1007/ s00468-014-1018-x 
Hasegawa, P. M. (2013) Sodium $\left(\mathrm{Na}^{+}\right)$. homeostasis and salt tolerance of plants. Environmental and Experimental Botany, 92(1):19-31. doi: 10.1016/j. envexpbot.2013.03.001

Kaushal, M., \& Wani, S. P. (2016). Rhizobacterialplant interactions: strategies ensuring plant growth promotion under drought and salinity stress. Agriculture, Ecosystems \& Environment, 231(1), 6878. doi: 10.1016/j.agee.2016.06.031

Larré, C. F., Moraes, D. M. de, \& Lopes, N. F. (2011). Qualidade fisiológica de sementes de arroz tratadas com solução salina e 24-epibrassinolídeo. Revista Brasileira de Sementes, 33(1), 86-94. doi: 10.1590/ S0101-31222011000100010

Lima, G. S. de, Dias, A. S., Gheyi, H. R., Soares, L. A. dos A., Nobre, R. G., Pinheiro, F. W. A., \& Silva, A. A. R. da. (2017). Gas exchanges and production of colored cotton under salt stress and nitrogen fertilization. Bioscience Journal, 33(6), 1495-1505. doi: 10.14393/BJ-v33n6a2017-37109

Lima, G. S. de, Santos, J. B. dos, Soares, L. A. dos A., Gheyi, H. R., Nobre, R. G., \& Pereira, R. F. (2016). Irrigação com águas salinas e aplicação de prolina foliar em cultivo de pimentão 'All Big'. Comunicata Scientiae, 7(4), 513-522. doi: 10.14295/ CS.v7i4.1671

Lima, M. de A., Castro, V. F. de, Vidal, J. B., \& Enéas, J., Fo. (2011). Aplicação de silício em milho e feijão-de-corda sob estresse salino. Revista Ciência Agronômica, 42(2), 398-403. doi: 10.1590/S180666902011000200019

Lucena, C. C. de, Siqueira, D. L. de, Martinez, H. E. P., \& Cecon, P. R. (2012). Efeito do estresse salino na absorção de nutrientes em mangueira. Revista Brasileira de Fruticultura, 34(1), 297-308. doi: 10.1590/ S0100-29452012000100039

Lúcio, W. da S., Lacerda, C. F. de, Mendes, P. F., F $^{\text {. }}$, Hernandez, F. F. F., Neves, A. L. R., \& Gomes, E., Fo. (2013). Crescimento e respostas fisiológicas do meloeiro inoculado com fungos micorrízicos arbusculares sob estresse salino. Semina: Ciências Agrárias, 34(4), 1587-1602. doi: 10.5433/1679-0359.2013v34n4p1587

Medeiros, P. R. F., Duarte, S. N., Uyeda, C. A., Silva, E. F. F., \& Medeiros, J. F. de. (2012). Tolerância da cultura do tomate à salinidade do solo em ambiente protegido. Revista Brasileira de Engenharia Agrícola e Ambiental, 16(1), 51-55. doi: 10.1590/ S1415-43662012000100007
Melo, A. S. de, Silva, C. D. da, Jr., Fernandes, P. D., Sobral, L. F., Brito, M. E. B., \& Dantas, J. D. M. (2009). Alterações das características fisiológicas da bananeira sob condições de fertirrigação. Ciência Rural, 39(3), 733-741. doi: 10.1590/S010384782008005000101

Moussa, H. R., \& Galad, M. A. R. (2015). Comparative response of salt tolerant and salt sensitive maize (Zea mays L.) cultivars to silicon. European Journal of Academic Essays, 2(1), 1-5.

Munns, R., \& Tester, M. (2008). Mechanisms of salinity tolerance. Annual Review of Plant Biology, 59(1), 651-681. doi: 10.1146/annurev. arplant.59.032607.092911

Novais, R. F., Neves, J. C. L., \& Barros, N. F. (1991). Ensaio em ambiente controlado. In: A. J. Oliveira, W. E. Garrido, J. D. Araújo, \& S. Lourenço (Eds.), Métodos de pesquisa em fertilidade do solo. Brasília: Embrapa SEA, 1991. p. 189-253.

Oliveira, A. P. de, Silva, O. P. R. da, Silva, J. A., Silva, D. F. da, Ferreira, D. T. de A., \& Pinheiro, S. M. G. (2014). Produtividade do quiabeiro adubado com esterco bovino e NPK. Revista Brasileira de Engenharia Agrícola e Ambiental, 18(10), 989-993. doi: 10.1590/1807-1929/agriambi.v18n10p989-993

Oliveira, W. J. de, Souza, E. R. de, Cunha, J. C., Silva, E. F. de F., \& Veloso, V. de L. (2017). Leaf gas exchange in cowpea and $\mathrm{CO}_{2}$ efflux in soil irrigated with saline water. Revista Brasileira de Engenharia Agrícola e Ambiental, 21(1), 32-37. doi: 10.1590/1807-1929/ agriambi.v21n1p32-37

Paes, H. M. F., Esteves, B. dos S., \& Sousa, E. F. de. (2012). Determinação da demanda hídrica do quiabeiro em Campos dos Goytacazes, RJ. Revista Ciência Agronômica, 43(2), 256-261. doi: 10.1590/ S1806-66902012000200007

Pang, C., \& Wang, B. (2008). Oxidative stress and salt tolerance in plants. Progress in Botany, 69(3), 231245. doi: 10.1007/978-3-540-72954-9 9

Prazeres, S. da S., Lacerda, C. F. de, Barbosa, F. E. L., Amorim, A. V., Araújo, I. C. da S., \& Cavalcante, L. F. (2015). Crescimento e trocas gasosas de plantas de feijão-caupi sob irrigação salina e doses de potássio. RevistaAgro@mbiente On-line,9(2),111-118. doi: 10.18227/1982-8470ragro.v9i2.2161

Rezende, R. A. L. S., Rodrigues, F. A., Soares, J. D. R., Silveira, H. R. de O., Pasqual, M., \& Dias, G. de M. G. (2018). Salt stress and exogenous silicon influence physiological and anatomical features of in vitro-grown cape gooseberry. Ciência Rural, 48(1), e20170176. doi: 10.1590/0103-8478cr20170176 
Richards, L. A. (1954). Diagnosis and improvement of saline and alkali soils. Washington: U. S. Department of Agriculture. Agriculture Handbook, 60.

Santos, H. C., Pereira, E. M., Medeiros, R. L. S. de, Costa, P. M. de A., \& Pereira, W. E. (2019). Production and quality of okra produced with mineral and organic fertilization. Revista Brasileira de Engenharia Agrícola e Ambiental, 23(2), 97-102. doi: 10.1590/1807-1929/agriambi.v23n2p97-102

Silva, E. N. da, Ribeiro, R. V., Ferreira-Silva, S. L., Viégas, R. A., \& Silveira, J. A. G. (2011a). Salt stress induced damages on the photosynthesis of physic nut young plants. Scientia Agricola, 68(1), 62-68. doi: 10.1590/S0103-90162011000100010

Silva, F. L. B. da, Lacerda, C. F. de, Sousa, G. G. de, Neves, A. L. R., Silva, G. L. da, \& Sousa, C. H. C. (2011b). Interação entre salinidade e biofertilizante bovino na cultura do feijão-de-corda. Revista Brasileira de Engenharia Agrícola e Ambiental, 15(4), 383-389. doi: 10.1590/S1415-43662011000400 009

Souto, A. G. L., Cavalcante, L. F., Diniz, B. L. M. T., Mesquita, F. O., Nascimento, J. A. M., \& Lima, A. J., Neto. (2015). Água salina e biofertilizante bovino na produção de frutos e alocação de biomassa em noni (Morinda citrifolia L.). Revista Brasileira de Plantas Medicinais, 17(2), 340-349. doi: 10.1590/1983084X/13_039
Souza, R. P., Machado, E. C., Silveira, J. A. G., \& Ribeiro, R. V. (2011). Fotossíntese e acúmulo de solutos em feijoeiro caupi submetido à salinidade. Pesquisa Agropecuária Brasileira, 46(6), 586-592. doi: 10. 1590/S0100-204X2011000600003

Suassuna, J. F., Fernandes, P. D., Brito, K. S. A. de, Nascimento, R. do, Melo, A. S. de, \& Brito, M. E. B. (2014). Trocas gasosas e componentes de crescimento em porta-enxertos de citros submetidos à restrição hídrica. Irriga, 19(3), 464-477. doi: 10.15809/irriga.2014v19n3p464

Vieira, I. G. S., Nobre, R. G., Dias, A. S., \& Pinheiro, F. W. A. (2016). Cultivation of cherry tomato under irrigation with saline water and nitrogen fertilization. Revista Brasileira de Engenharia Agrícola e Ambiental, 20(1), 55-61. doi: 10.1590/1807-1929/ agriambi.v20n1p55-61

Zhu, Y., \& Gong, H. (2014). Beneficial effects of silicon on salt and drought tolerance in plants. Agronomy for Sustainable Development, 34(2), 455-472. doi: 10.1007/s13593-013-0194-1 
